\title{
Transfer of ${ }^{137} \mathrm{Cs}$ from water to fish is not linear in two northern lakes
}

\author{
Tiina S. Tuovinen • Chutarat Saengkul • \\ Jarkko Ylipieti · Dina Solatie · Jukka Juutilainen
}

Received: 13 June 2011/Revised: 29 April 2012/Accepted: 9 June 2012/Published online: 31 July 2012

(C) The Author(s) 2012. This article is published with open access at Springerlink.com

\begin{abstract}
Empirical data on the behavior of radionuclides in the biosphere are needed for validating radioecological models. In this study, data collected from two lakes in Northern Finland were used to investigate the transfer of ${ }^{137} \mathrm{Cs}$ from lake water into fish during a 20-year period after the Chernobyl nuclear power plant accident. The results indicated that transfer of ${ }^{137} \mathrm{Cs}$ in the food chains investigated is nonlinear: the water-to-fish concentration ratios (CRs) decreased with increasing ${ }^{137} \mathrm{Cs}$ concentration in water. Major deviation from linearity (constant CR) commonly assumed in radioecological modeling was observed only at low ${ }^{137} \mathrm{Cs}$ concentrations in water. Other findings of potential importance for
\end{abstract}

Handling editor: David J. Hoeinghaus

T. S. Tuovinen $(\bowtie) \cdot$ C. Saengkul · J. Juutilainen Department of Environmental Science, University of Eastern Finland, P.O. Box 1627, 70211 Kuopio, Finland e-mail: tiina.boman@uef.fi

Present Address:

C. Saengkul

Center of Excellence on Environmental Health, Toxicology and Management of Chemicals, Department of Environmental Science, Faculty of Science,

Burapha University, 20131 Chonburi, Thailand

J. Ylipieti · D. Solatie

Research and Environmental Surveillance, Regional Laboratory in Northern Finland, STUK-Radiation and Nuclear Safety Authority, Lähteentie 2,

96400 Rovaniemi, Finland radioecological models were that ${ }^{137} \mathrm{Cs}$ concentrations were threefold higher in piscivores than in nonpiscivores and that no differences in ${ }^{137} \mathrm{Cs}$ uptake were found between the two piscivorous species (pike and perch) studied or between three non-piscivorous species (vendace, white fish, and roach) representing different feeding habits (planktivore, benthivore, and mixed diet).

Keywords Radioecology · Transfer factor . Linearity assumption - Trophic transfer $\cdot{ }^{137} \mathrm{Cs}$. Aquatic

\section{Introduction}

Radioecological modeling is commonly used for predicting transfer of radionuclides in ecosystems, estimating doses, and assessing possible adverse effects on human health and wildlife. The ability of radioecological models to accurately predict concentrations and doses depends critically on empirical data on the behavior of specific radionuclides in the biosphere and on the correctness of basic assumptions used in the models.

Chernobyl nuclear power plant accident in 1986 is a major source of empirical data associated with radioecological modeling. The long-term fall-out from the Chernobyl accident consisted largely of the radionuclides of Cs, notably ${ }^{137} \mathrm{Cs}$, which was discharged into terrestrial, freshwater, and marine environments and is 
taken up by organisms into the food chain. In Finland, the most contaminated sites were in the middle of Southern Finland, whereas Northern Finland was the least contaminated because of distance from Chernobyl, speed and direction of wind, and intermittent rain (Arvela et al., 1990).

In radioecological modeling, transfer of radionuclides is commonly described by concentration ratios (CRs). For example, the $\mathrm{CR}$ for the relationship between fish and water radionuclide levels is defined as the activity concentration in fish $\left(\mathrm{Bq} \mathrm{kg}^{-1}\right.$ wet wt) divided by the activity concentration in water $\left(\mathrm{Bq}^{-1}\right)$ (IAEA, 2010). The use of CRs is based on the assumption that the transfer of elements is linear, i.e., that the CR for an element is, under comparable condition, constant regardless of the element concentration in the substrate such as soil or water. However, data on uptake from soil to plants are not consistent with the linearity assumption, indicating more effective uptake at low than high concentrations (Timperley et al., 1970; Sheppard \& Sheppard, 1985; Simon \& Ibrahim, 1987; Palm, 1994; Marschner, 1995; Krauss et al., 2002; Han et al., 2006; Tuovinen et al., 2011), and there is also some evidence indicating that transfer from water to fish may not be linear (Pyle \& Clulow, 1997).

Although the size of fish and trophic level can be expected to influence the level of ${ }^{137} \mathrm{Cs}$ in different species of fish (Sundbom et al., 2003), empirical data are scarce, and radioecological models typically assume that the CR values for different fish species are the same. For example, the ERICA Tool, which is a software program developed within the EC EURATOM-funded ERICA project to assess radiological risks to biota, assumes that $\mathrm{CR}$ values of fresh water fish depend only on habitat, with higher CR value for benthic fish than pelagic fish (Brown et al., 2008; Hosseini et al., 2008).

In the present study, data from two lakes in Finnish Lapland were used to investigate the relationship between ${ }^{137} \mathrm{Cs}$ concentrations in water and fish. The data were available, because the Finnish Radiation and Nuclear Safety Authority had carried out long-term monitoring after the Chernobyl accident in these lakes. The two lakes differ by size and level of nutrients, which offered a possibility to address possible lakespecific differences in the transfer of ${ }^{137} \mathrm{Cs}$. The dataset included activity concentrations for several fish species with different niches and trophic levels (planktivores, benthivores, and piscivores) in the lake ecosystem, which allowed us to investigate interspecies differences in transfer of ${ }^{137} \mathrm{Cs}$. As the data were collected from an area in Northern Finland where the

${ }^{137} \mathrm{Cs}$ fallout level was low, they are suitable for investigating the possible nonlinearity, which most likely affects uptake into the food chain at low substrate concentrations.

\section{Materials and methods}

Lake Inari is a large $\left(1,040 \mathrm{~km}^{2}\right)$ oligotrophic lake in the northern part of Finnish Lapland (69N, 28E), whereas Lake Apukka is a small $\left(0.48 \mathrm{~km}^{2}\right)$, shallow, and highly eutrophic lake near the Arctic Circle (67N, 26E) (Fig. 1). Samples of fish and water from both lakes were collected annually. The fish samples were collected between 1986 and 2007 from Lake Inari and between 1982 and 2006 from Lake Apukka. The fish species sampled from Lake Inari were pike (Esox lucius), perch (Perca fluviatilis), vendace (Coregonus albula). and white fish (Goregonus lavaretus). while samples of pike, perch, and roach (Rutilus rutilus) were collected from Lake Apukka. The fish samples were collected during summer from Lake Apukka, while both winter and summer samples were obtained from Lake Inari. Before measurement of gammaemitting nuclides, the samples were pre-treated. Depending on sample size, the fish meat was either measured in a $500 \mathrm{ml}$ Marinelli beaker as fresh, or in case of smaller samples, they were dried, minced, and placed into a $25-$ or $100-\mathrm{ml}$ plastic beaker. The drying was done in an oven at $105^{\circ} \mathrm{C}$ typically for $30 \mathrm{~h}$. Samples of lake water were taken 1-5 times per year from 1988 to 2005, during both summer and winter months. One sample consisted of about 201 of water. The water was placed into beakers covered with plastic foils and evaporated for 2-3 days under infrared lights. The dry matter and plastic foils were finally ashed at $550^{\circ} \mathrm{C}$, and the ashes were placed into a 25-ml plastic beaker.

The activity concentrations of ${ }^{137} \mathrm{Cs}$ in water and fish samples were measured by gamma spectrometry in the laboratory of the Radiation and Nuclear Safety Authority (STUK). The activity concentration was determined using the Gamma-99 software developed at STUK.

Yearly geometric means were calculated for the water samples. Activity concentrations of ${ }^{137} \mathrm{Cs}$ in fish were expressed per fresh weight (fw). The relationship 


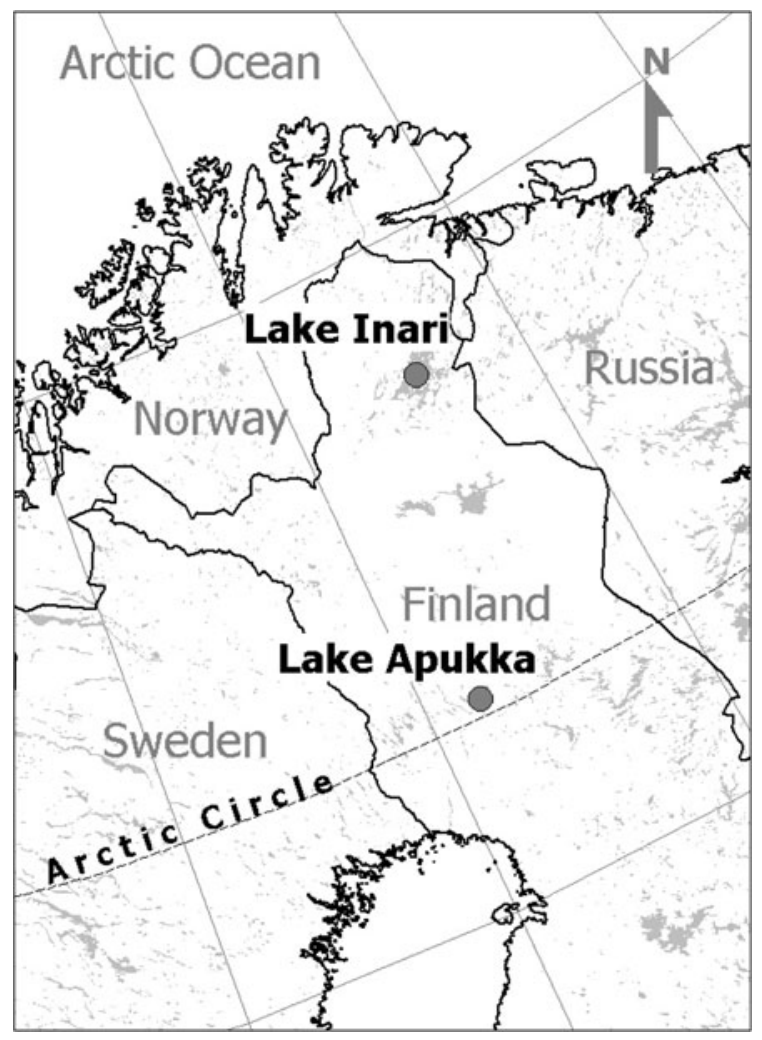

Fig. 1 Locations of Lake Apukka and Lake Inari in Northern Finland

between CRs and concentrations in lake water was studied by nonlinear regression analysis using GraphPad Prism version 4.03 for Windows (GraphPad Software Inc.).

\section{Results}

${ }^{137} \mathrm{Cs}$ concentration in lake water

Soon after the Chernobyl accident, the ${ }^{137} \mathrm{Cs}$ concentration of water was close to $0.02 \mathrm{~Bq} \mathrm{l}^{-1}$ in Lake Inari and around $0.005 \mathrm{~Bq}^{-1}$ in Lake Apukka (Fig. 2). A clear decrease was seen in both lakes by 1993, and only low values around $0.001 \mathrm{~Bq}^{-1}$ or below were seen after 1997 (1999 in Lake Inari). Although data on water concentration were lacking between 1993 and 1997 in Lake Apukka and between 1993 and 1998 in Lake Inari, the data are consistent with relatively short ecological half-lives and the concentrations reaching a steady-state level by the end of the 1990s in both these lakes.
${ }^{137}$ Cs concentration in fish during 1982-2006

The ${ }^{137} \mathrm{Cs}$ concentrations in pike and perch in Lake Apukka peaked in 1987, 1 year after the Chernobyl nuclear power plant accident, with maximum recorded activity concentration being $120 \mathrm{~Bq} \mathrm{~kg}^{-1} \mathrm{fw}$ in both species (Fig. 3). There are no data on roach at the time of the highest peak, but a decrease to one-third of the initial value was seen between 1989 and 1997 . The ${ }^{137} \mathrm{Cs}$ concentrations in pike and perch were consistently higher than in roach.

In Lake Inari, the highest ${ }^{137} \mathrm{Cs}$ concentration in perch was observed in 1986, but no data on 1986 concentrations are available for the other species (Fig. 3). In 1987, the concentration in pike, perch, vendace, and whitefish were $210,237,62$, and $62 \mathrm{~Bq} \mathrm{~kg}^{-1} \mathrm{fw}$, respectively, with decreasing trends until about 2000. Consistent with the findings in Lake Apukka, the ${ }^{137} \mathrm{Cs}$ concentrations of pike and perch were higher compared with other fish species.

Comparison of the activity concentrations in water (Fig. 2) and in fish (Fig. 3) indicated that the concentrations in fish follow concentrations in water with very short delay.

Transfer from water to fish: concentration ratio

The time-dependent decrease of ${ }^{137} \mathrm{Cs}$ concentration was lower in fish than in water, indicating that the water-to-fish CRs increased with time (and with decreasing concentration in water). When the waterto-fish CRs were plotted as a function of activity concentration in lake water, the $\mathrm{CR}$ values were the highest at low water concentrations and seemed to asymptotically approach a low constant value at high concentrations in water (Fig. 4). A function that we have found to describe uptake of elements from soil to plants (Tuovinen et al., 2011) fitted well with the data. The function is of the following form:

$\mathrm{CR}=a /\left(1+b C_{\mathrm{s}}\right)+c$,

where $a, b$, and $c$ are experimentally determined parameters, and $C_{\mathrm{s}}$ is concentration in the substrate (soil in the case of uptake into terrestrial plants; lake water in the current study). The value of $\mathrm{CR}$ at substrate concentration 0 is $a+c$, parameter $b$ determines the shape of the function at rising concentrations, and parameter $c$ represents the level that CR approaches at high substrate concentrations. The 

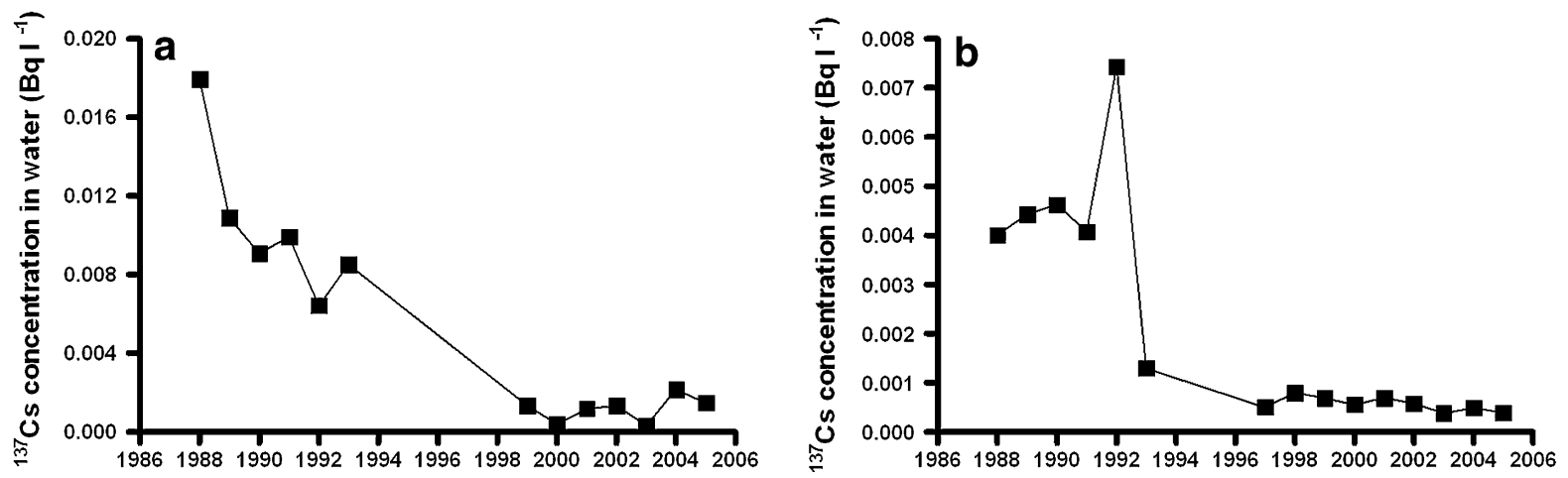

Fig. 2 Activity concentrations of ${ }^{137} \mathrm{Cs}$ in water in Lake Inari (a) and Lake Apukka (b)
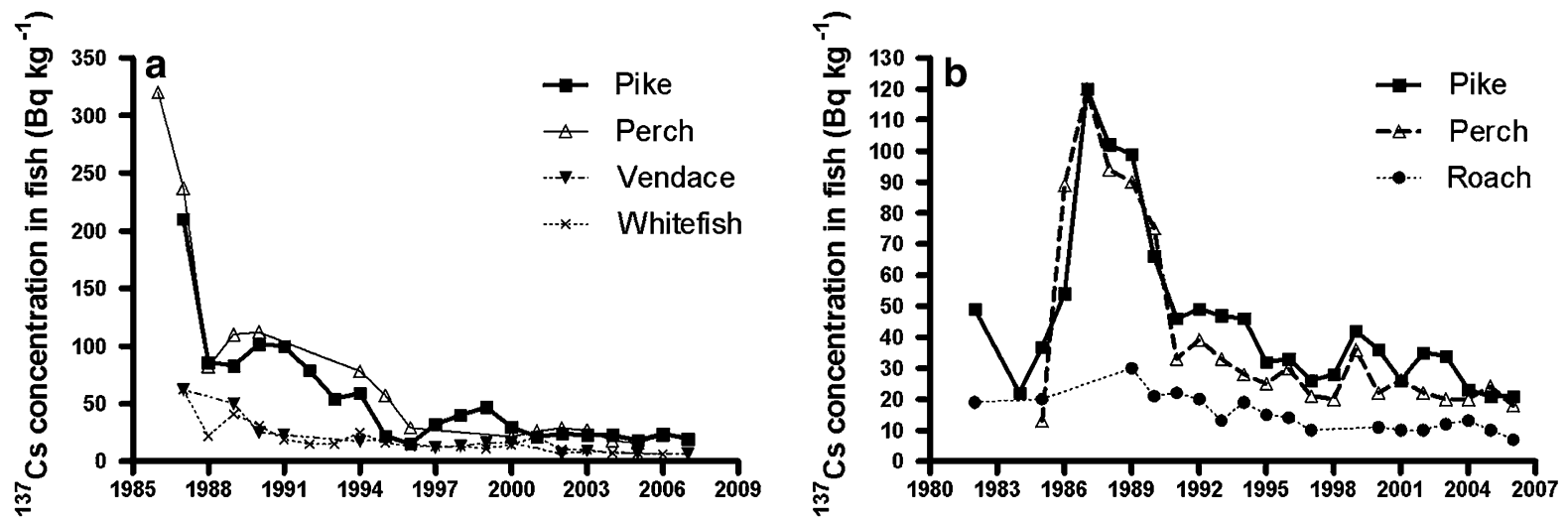

Fig. 3 Activity concentrations of ${ }^{137} \mathrm{Cs}\left(\mathrm{Bq} \mathrm{kg}^{-1}\right.$ fresh weight) in fish in Lake Inari (a) and Lake Apukka (b)

curves in Fig. 3 resulted from fitting this function with the data. Good fits (high $R^{2}$ values) were observed in all cases. As expected based on the fish concentration data, the $\mathrm{CR}$ values for perch and pike were higher than those for whitefish, vendace, and roach. Comparison of the CR curves for Apukka and Inari did not suggest any obvious differences between the two lakes.

Transfer of ${ }^{137} \mathrm{Cs}$ from fish to fish

To assess transfer on ${ }^{137} \mathrm{Cs}$ between fish species in the aquatic food chain, prey-to-predator CRs were calculated. Such CRs were found to be constant as a function of ${ }^{137} \mathrm{Cs}$ concentration in water (Fig. 5), suggesting linear transfer at this level of the food chain. The means (with their $95 \%$ confidence intervals) of CRs for different prey-to-predator combinations (vendace-to-pike, roach-to-pike, whitefish-to-pike, and vendace-to-perch) were $2.9 \pm 0.47,2.6 \pm 0.25$,
$2.8 \pm 0.45$, and $3.2 \pm 0.69$, respectively. Pooled CR for all combinations was $2.9 \pm 0.23$.

\section{Discussion}

This study produced three findings that may be important for radioecology in freshwater ecosystem. Transfer of ${ }^{137} \mathrm{Cs}$ from lake water to fish was nonlinear. Transfer of ${ }^{137} \mathrm{Cs}$ from water to piscivores was approximately three times higher than from water to non-piscivores. There was no difference between transfers of ${ }^{137} \mathrm{Cs}$ from water to planktivores and benthivores.

\section{Nonlinearity of transfer}

In this study, the effect of water concentration on CR was studied only by comparing CRs measured at different times in the same lake. This approach could 

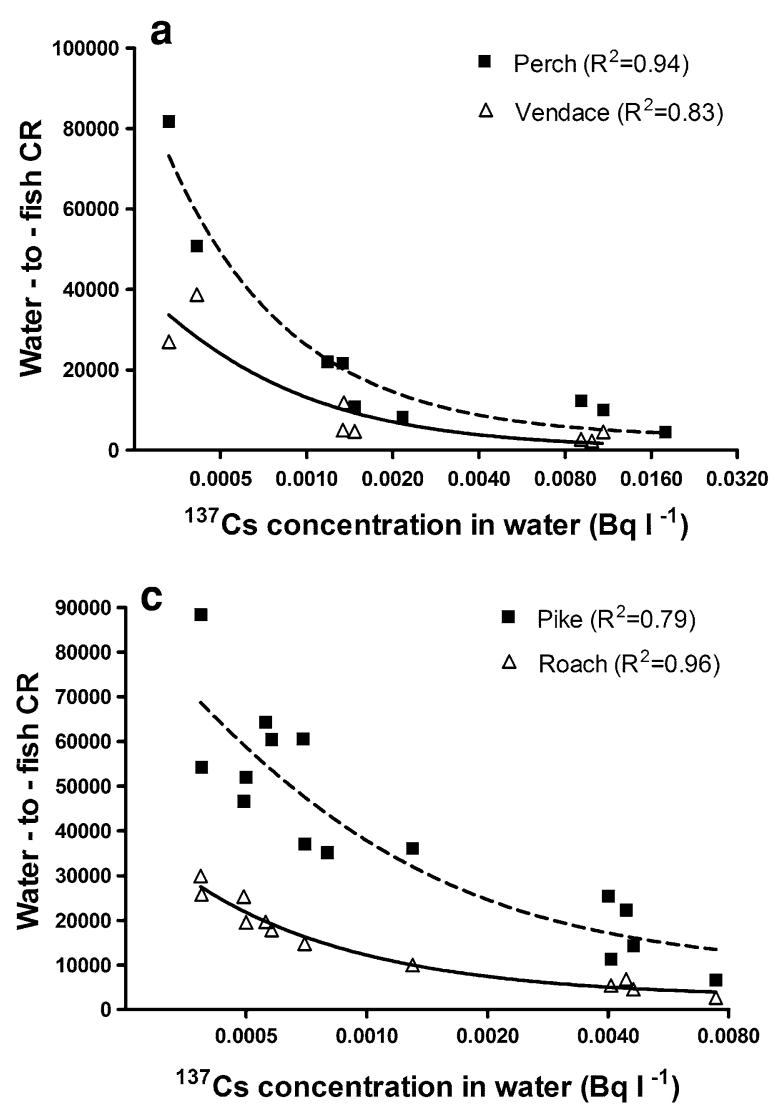

Fig. 4 Water-to-fish concentration ratios $(\mathrm{CR})$ as a function of water ${ }^{137} \mathrm{Cs}$ concentration in Lake Inari $(\mathbf{a}, \mathbf{b})$ and in Lake Apukka (c). The lines represent the fitted nonlinear equation of

produce misleading results, if Cs persisted in fish tissues for years, as the concentrations in fish observed during the later years would reflect Cs accumulation from the peak exposure at the time of the Chernobyl accident. However, a significant effect of this type is not plausible for several reasons. The transfer pathway of Cs into fish can be described by an uptake-loss model consisting of uptake from water by producers and further transfer by consumption to first-order and second-order consumers (Pinder et al., 2009, 2011). At all trophic levels, loss of Cs from biota occurs because of excretion, mortality, migration, and other causes. The biological half-life for loss due to excretion, determined in fish contaminated by ${ }^{137} \mathrm{Cs}$ and then kept in uncontaminated water, is of the order of tens to hundreds of days (Ugedal et al., 1992; Peters \& Newman, 1999; Malek et al., 2004). This implies that the long ecological half-lives (up to tens of years) observed in fish growing in natural conditions

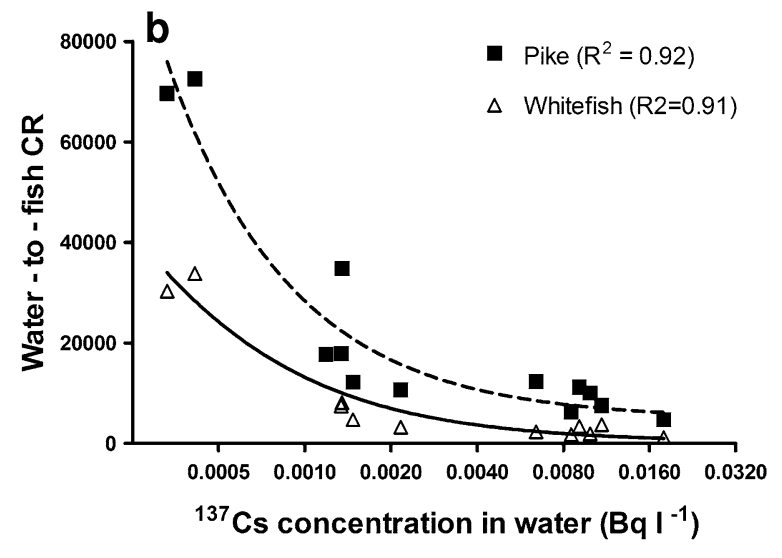

the form $\left(Y=a /\left(1+b C_{\mathrm{s}}\right)+c\right)$, and $R^{2}$ values are given to describe the goodness of fit

(Sundbom et al., 2003) result from continuous uptake of ${ }^{137} \mathrm{Cs}$ from the food chain, and that the Cs taken up at the time of peak concentrations did not persist in fish tissues during the 20-year follow-up of the present study. This conclusion is supported by the fast decrease of concentration in fish during the first years after the Chernobyl accident (Fig. 3). Moreover, vendace is a short-lived species, and the individuals of the other species were typically relatively young (judged by size), so all fish samples represent recent transfer of Cs from the food chain.

Measurements performed simultaneously in other lakes with different ${ }^{137} \mathrm{Cs}$ concentrations would comprise an independent check for the nonlinear model used in the present study. Such data are available in the study by Saxen et al. (2010) who reported CRs for pike and perch from 1987 to 2006 in four southern Finland lakes, in which the ${ }^{137} \mathrm{Cs}$ activity concentrations were much higher than in the present study $\left(1.4-4.1 \mathrm{~Bq}^{-1}\right.$ 

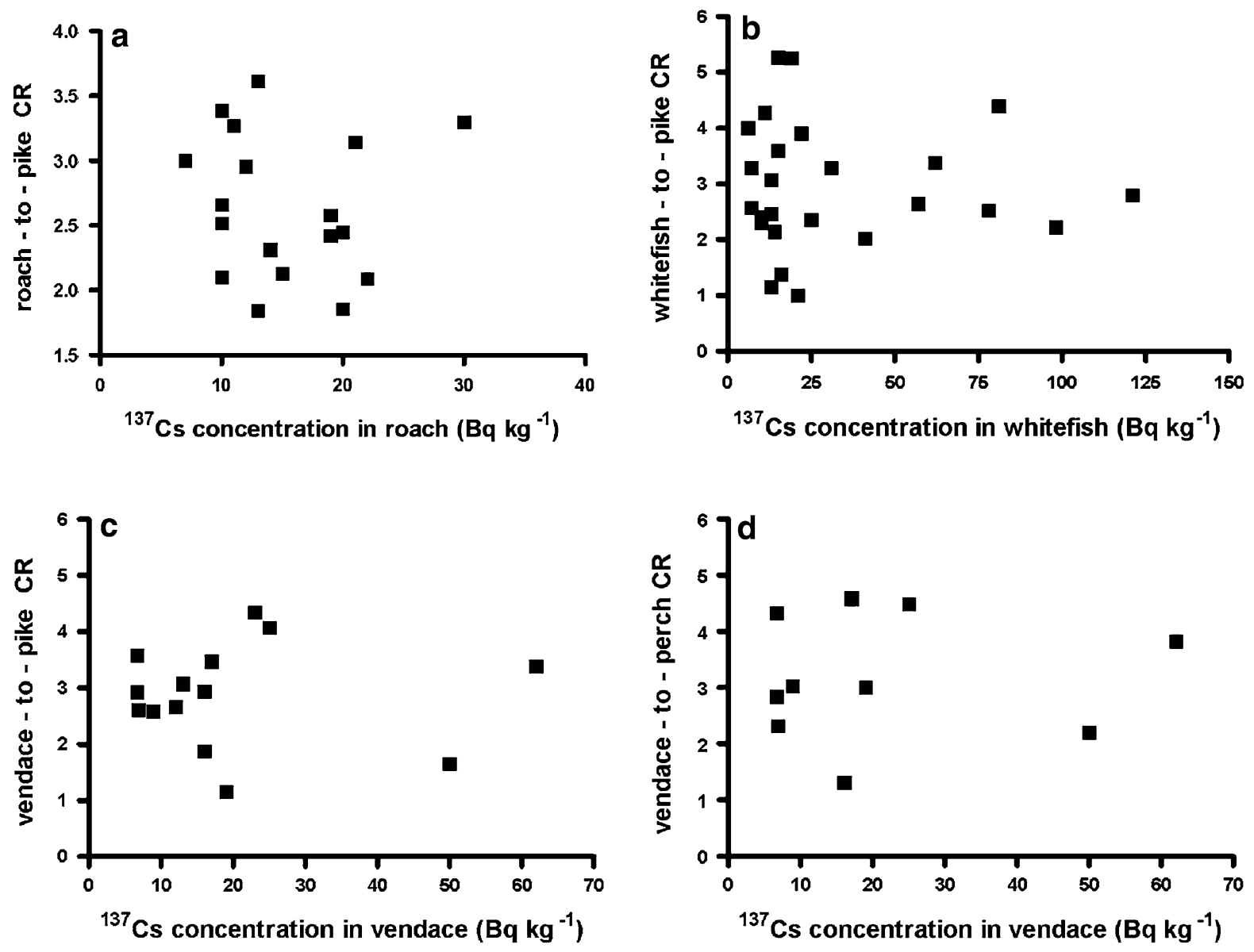

Fig. 5 Prey-to-predator concentration ratios (CRs) as a function of ${ }^{137} \mathrm{Cs}$ concentration in prey (Bq $\mathrm{kg}^{-1}$ fresh weight) for different prey-to-predator combinations

in 1987; 0.21-0.44 $\mathrm{Bq} 1^{-1}$ in 2006). They reported CR values from 1,700 to 21,000 (slightly higher values for pike than perch) with an overall mean of 6,000. These values are consistent with the observations of the present study: the curves for pike and perch shown in Fig. 4 suggested an asymptotic CR value around 10,000 or below at high ${ }^{137} \mathrm{Cs}$ concentrations in water. There was some evidence that $\mathrm{CR}$ changes with time (with decreasing concentration in water) also in Saxen et al.'s data, but the changes were small compared to those observed in the present study and possibly influenced by low number of measurements at late points in time. Also, the direction of change was not consistent between two types of lakes, with decreasing $\mathrm{CR}$ in drainage lakes and increasing $\mathrm{CR}$ in seepage lakes. As both Lake Apukka and Lake Inari are drainage lakes, our data showing marked increase of $\mathrm{CR}$ values with time was not consistent with the decrease suggested by Saxen et al. (2010). Together, ours and Saxen et al.'s data suggested a relatively constant $\mathrm{CR}$ at high water concentrations and enhanced transfer into fish at low concentrations in water.

The present findings confirm previous observations (Pyle \& Clulow, 1997) suggesting that transfer of ${ }^{137} \mathrm{Cs}$ from water to fish is not linear: the CRs (which should be constant under the linearity assumption) were found to increase with decreasing ${ }^{137} \mathrm{Cs}$ concentration in water. These findings (including the shape of the CR curves shown in Fig. 4) are similar to our findings in terrestrial ecosystem, where soil-to-plant CRs for several elements showed a similar dependency on soil concentration. (Tuovinen et al., 2011). It is tempting to assume that uptake by phytoplankton or aquatic plants of elements dissolved in water would be similar to uptake by terrestrial plants of elements 
dissolved in soil water. This first step in radionuclide uptake might be the only nonlinear step in the food chain. Our data on the transfer from fish to fish support this hypothesis: the CR for transfer from non-piscivorous to piscivorous fish was found to be constant, indicating linear transfer. Data on ${ }^{137} \mathrm{Cs}$ concentrations at the first trophic levels of the aquatic ecosystem were not available in this study, but the nonlinear nature of uptake from water to algae has been well characterized in studies on biosorption, removal of metals or radionuclides from aqueous solution by biological materials (biosorbents). Several studies have shown that the biosorption of metals into live or dead algae is nonlinear and approximately follows Langmuir- or Freundlich-type equations (Volesky \& Schiever, 1999; Klimmek et al., 2001; Davis et al., 2000; Havari and Mulligan, 2006; Doshi et al., 2007; Katircioglu et al., 2008; Shashirekha et al., 2008; Doshi et al., 2009).

\section{Differences between species}

The fish species studied included both piscivorous and three different non-piscivorous species. Pike is a typical piscivorous fish feeding on other fish species such as vendace and roach. As a fast growing species, it feeds on zooplankton and larvae for only a short period during its early life. Perch is a smaller species that feeds on fish, zooplankton, and benthic animals. Roach is one of the most common fish species in Finnish lakes, mostly because of diversity of its diet, including zooplankton, all kinds of benthos, and even aquatic plants, i.e., almost anything suitable for nonpiscivorous fish. Vendace is a small fish species feeding on zooplankton. There are different forms of whitefish, including both planktivores and benthivores. Because the benthivorous form of whitefish has been restocked into Lake Inari since 1975, the whitefish investigated in the present study can be considered a benthivore. The fish species studied have lifetimes of more than 20 years in favorable conditions, excluding vendace, which has a life span of 4-6 years. Of the fish species studied, pike is the largest (up to $20-30 \mathrm{~kg}$ at the age of 20 years), followed by whitefish, perch, roach, and vendace.

Although radioecological models do not necessarily include different $\mathrm{CR}$ values for fish species representing different trophic levels, it is well known that accumulation of $\mathrm{Cs}$ is higher in organisms that are at higher levels in the food chain. Our finding of higher ${ }^{137} \mathrm{Cs}$ levels and $\mathrm{CR}$ values in piscivorous species (pike and perch) than in the other species is consistent with numerous other studies showing that ${ }^{137} \mathrm{Cs}$ activity concentrations increase with increasing trophic level in aquatic ecosystems (Rowan and Rasmussen, 1994; Rowan et al., 1998; Smith et al., 2000; Burger et al., 2001; Yoshutome et al., 2003; Brittain and Gjerseth, 2010; Fesenko et al., 2011) and strengthens the need to use different transfer functions for piscivores and non-piscivores. It is of interest that all three non-piscivorous species, in spite of their different feeding habits (a planktivore, a benthivore, and a species with mixed diet), showed very similar uptake of ${ }^{137} \mathrm{Cs}$. This result does not support using different transfer functions for pelagic and benthic fish species in radioecological models describing northern freshwater ecosystems, and suggests that ${ }^{137} \mathrm{Cs}$ present in sediment does not essentially increase transfer of Cs into the benthivorous fish species studied. Only three non-piscivorous species were included, and so the results might not be valid for all such freshwater species. However, all these three species are common in northern lakes, important links in the food chain and relevant to human consumption of fish (of these species, roach is the only one that is not commonly used as human food, but it is an important feed to pike).

\section{Comparison of the lakes}

There are findings suggesting that uptake of ${ }^{137} \mathrm{Cs}$ into fish might be higher in oligotrophic than in eutrophic lakes (Sarkka et al., 1996; Saxen \& Koskelainen, 2005; Saxen \& Ilus, 2008). The results of the present study did not provide evidence for such differences, as the CR curves were similar in a eutrophic (Lake Apukka) and an oligotrophic (Lake Inari) lake. Also, the transfer functions found in this study seem to be consistent with the data collected by Saxen et al. (2010) in four different lakes in southern Finland. However, the processes that determine the accumulation of ${ }^{137} \mathrm{Cs}$ in fish are complex, and several environmental factors, such as water temperature, $\mathrm{pH}$, water salinity, nutrients in water, organic matter content, potassium content, sedimentation rate, and type of sediment (Rowan \& Rasmussen, 1994; Sarkka et al., 1996; Smith et al., 2000, 2002; Topcuoglu, 2001; Ilus \& Saxen, 2005; Saxen \& Koskelainen, 
2005; Saxen \& Ilus, 2008; Brittain \& Gjerseth, 2010; Saxen et al., 2010; Strand \& Dowdall, 2010; Fesenko et al., 2011), may affect Cs uptake. Data on such factors were not available in this study. Additional studies in different lakes would be useful to confirm whether the transfer functions determined is this study can be used to quantitatively estimate ${ }^{137} \mathrm{Cs}$ uptake in different types of lakes.

\section{Conclusions}

Based on the results of this study, a nonlinear transfer function describes transfer of ${ }^{137} \mathrm{Cs}$ into fish. The data were limited to five fish species in two different types of lakes, but they suggest that the level of transfer might differ only between piscivores and non-piscivores. The transfer function appeared to be similar in the three non-piscivorous species independent of feeding habits (planktivore, benthivore, or mixed diet). Also, no difference was observed between the two piscivorous species. The nonlinear transfer function resulted in major differences from linear models (constant CR) only at low water concentrations. For transfers between species at different trophic levels, the findings were consistent with linear transfer, and modeling could be based on a constant $C R$ value of about 3 between piscivores and non-piscivores.

Acknowledgments Tiina S. Tuovinen was supported by a grant from the State Nuclear Waste Management fund. Chutarat Saengul and her visit to the University of Eastern Finland was supported by the Bridging the Gap EMECW L 12 Project.

Open Access This article is distributed under the terms of the Creative Commons Attribution License which permits any use, distribution, and reproduction in any medium, provided the original author(s) and the source are credited.

\section{References}

Arvela, H., M. Markkanen \& H. Lemmelä, 1990. Mobile survey of environmental gamma radiation and fall-out levels in Finland after the Chernobyl accident. Radiation Protection Dosimetry 32: 177-184.

Brittain, J. E. \& J. E. Gjerseth, 2010. Long-term trends and variation in ${ }^{137} \mathrm{Cs}$ activity concentrations in brown trout (Salmo trutta) from Ovre Heimdalsvatn, a Norwegian subalpine lake. Hydrobiologia 642: 107-113.
Brown, J. E., B. Alfonso, R. Avila, N. A. Beresford, D. Copplestone, G. Prohl \& A. Ulanovsky, 2008. The ERICA Tool. Journal of Environmental Radioactivity 99: 13711383.

Burger, J., K. F. Gaine, J. D. Peles, W. L. Stephens Jr., C. S. Boring, I. L. Brisbin, J. Snodgrass, A. L. Bryan, M. H. Smith \& M. Gochfeld, 2001. Radiocesium in fish from the Savannah River and Steel Creek: potential food chain exposure to the public. Risk Analysis 21: 545-559.

Davis, T., B. Volesky \& R. H. S. F. Vieira, 2000. Sargassum seaweed as biosorbents for heavy metals. Water Research 34: 4270-4278.

Doshi, H., A. Ray \& I. L. Kothari, 2007. Bioremediation potential of live and dead Spirulina: spectroscopic, kinetics and SEM studies. Biotechnology and Bioengineering 96: 1051-1063.

Doshi, H., A. Ray \& I. L. Kothari, 2009. Live and dead Spirulina sp. to remove arsenic $(\mathrm{V})$ from water. International Journal of Phytoremediation 11: 53-64.

Fesenko, S., J. Fesenko, N. Sanzharova, E. Karpenko \& I. Titov, 2011. Radionuclide transfer to freshwater biota species: review of Russian language studies. Journal of Environmental Radioactivity 102: 8-22.

Han, F. X., Y. Su, D. L. Monts, C. A. Waggoner \& M. J. Plodinec, 2006. Binding, distribution and plant uptake of mercury in a soil from Oak Ridge, Tennessee, USA. Science of Total Environment 368: 753-768.

Havari, A. \& C. Mulligan, 2006. Biosorption of lead (II), cadmium (II), copper (II) and nickel (II) by anaerobic granular biomass. Bioresource Technology 97: 692-700.

Hosseini, A., H. Thorring, R. Brown, R. Saxen \& E. Ilus, 2008. Transfer of radionuclides in aquatic ecosystems - default concentration ratios for aquatic biota in the Erica Tool. Journal of Environmental Radioactivity 99: 1408-1429.

IAEA, 2010. Handbook of parameter values for the prediction of radionuclide transfer in terrestrial and freshwater environments. Technical Reports Series No. 472. International Atomic Energy Agency, Vienna. ISBN 978-92-0-1130099.

Ilus, E. \& R. Saxen, 2005. Accumulation of Chernobyl-derived ${ }^{137} \mathrm{Cs}$ in bottom sediments of some Finnish lakes. Journal of Environmental Radioactivity 82: 199-221.

Katircioglu, H., B. Ashm, A. Rehber Türker, T. Atici \& Y. Beyath, 2008. Removal of cadmium (II) ion from aqueous system by dry biomass, immobilized live and heat-inactivated Oscillatoria sp. $\mathrm{H} 1$ isolated from freshwater (Mogan Lake). Bioresource Technology 99: 4185-4191.

Klimmek, S., H. Stan, A. Wilke, G. Bunke \& R. Buchholz, 2001. Comparative analysis of the biosorption of cadmium, lead, nickel and zinc by algae. Environmental Science and Technology 35: 4283-4288.

Krauss, M., W. Wilcke, J. Kobza \& W. Zech, 2002. Predicting heavy metal transfer from soil to plant: potential use of Freundlich-type functions. Journal of Plant Nutrition and Soil Science 165: 3-8.

Malek, M. A., M. Nakahara \& R. Nakamura, 2004. Uptake, retention and organ/tissue distribution of ${ }^{137} \mathrm{Cs}$ by Japanese catfish (Silurus asotus Linnaeus). Journal of Environmental Radioactivity 77: 191-204.

Marschner, H., 1995. Mineral Nutrition of Higher Plants, 2nd ed. Academic Press Limited, London. 
Palm, V. A., 1994. Model for sorption, flux and plant uptake of cadmium in a soil profile: model structure and sensitivity analysis. Water, Air and Soil Pollution 77: 169-190.

Peters, E. L. \& M. C. Newman, 1999. ${ }^{137}$ Cs elimination by chronically-contaminated largemouth bass (Micropterus salmoides). Health Physics 76: 260-268.

Pinder J. E. III, T. G. Hinton, F. W. Whicker \& J. T. Smith, 2009. Cesium accumulation by fish following acute input to lakes: a comparison of experimental and Chernobylimpacted systems. Journal of Environmental Radioactivity 100: 456-467.

Pinder, J. E. III, T. G. Hinton, B. E. Taylor \& F. W. Whicker, 2011. Cesium accumulation by aquatic organisms at different trophic levels following an experimental release into a small reservoir. Journal of Environmental Radioactivity 102: 283-293.

Pyle, G. G. \& F. V. Clulow, 1997. Non-linear radionuclide transfer from the aquatic environment to fish. Health Physics 73: 488-493.

Rowan, D. J. \& J. B. Rasmussen, 1994. Bioaccumulation of radiocesium by fish: the influence of physicochemical factors and tropic structure. Canadian Journal of Fisheries and Aquatic Science 51: 2388-2410.

Rowan, D. J., L. A. Chant \& J. B. Rasmussen, 1998. The fate of radiocesium in freshwater communities - why is biomagnifications variable both within and between species? Journal of Environmental Radioactivity 40: 15-36.

Sarkka, J., A. Keskitalo \& A. Luukko, 1996. Temporal changes in concentration of radiocaesium in lake sediment and fish of southern Finland as related to environmental factors. The Science of the Total Environment 1991: 125-136.

Saxen, R. \& E. Ilus, 2008. Transfer and behavior of ${ }^{137} \mathrm{Cs}$ in two Finnish lakes and their catchments. Science of the Total Environment 394: 349-360.

Saxen, R. \& U. Koskelainen, 2005. ${ }^{137} \mathrm{Cs}$ in fishes and water in Finnish lakes - considerations for radiological risk assessment. Radioprotection 40: 649-654.

Saxen, R., S. Heinavaara, M. Rask, J. Ruuhijarvi \& H. Rand, 2010. Transfer of ${ }^{137} \mathrm{Cs}$ into fish in small forest lakes. Journal of Environmental Radioactivity 101: 647-653.

Shashirekha, V., M. R. Spidharan \& M. Swamy, 2008. Biosorption of trivalent chromium by free and immobilized blue green algae: kinetics and equilibrium studies. Journal of Environmental Science and Health Part A 43: 390-401.

Sheppard, M. I. \& S. C. Sheppard, 1985. The plant concentration ratio concept as applied to natural U. Health Physics 48: 494-500.
Simon, S. L. \& S. A. Ibrahim, 1987. The plant/soil concentration ratio for calcium, radium, lead and polonium: evidence for non-linearity with references to substrate concentration. Journal of Environmental Radioactivity 5: 123-142.

Smith, J. T., A. V. Kudelsky, I. N. Ryabov \& R. H. Hadderingh, 2000. Radiocesium concentration factors of Chernobyl contaminated fish: a study of the influence of potassium, and "blind" testing of a previously developed model. Journal of Environmental Radioactivity 48: 359-369.

Smith, J. T., A. V. Kudelsky, I. N. Ryabov, S. E. Daire, L. Boyer, R. J. Blust, J. A. Fernandez, R. H. Hadderingh \& O. V. Voitsekhovitch, 2002. Uptake elimination of radiocaesium in fish and the "size effect". Journal of Environmental Radioactivity 62: 145-164.

Strand, P. \& M. Dowdall, 2010. Radioecology and environmental exposure pathways. In Proceedings of third European IRPA Congress 2010, June 14-16, Helsinki, Finland.

Sundbom, M., M. Meili, E. Andersson, M. Östlund \& A. Broberg, 2003. Long-term dynamics of Chernobyl ${ }^{137} \mathrm{Cs}$ in freshwater fish: quantifying the effect of body size and trophic level. Journal of Applied Ecology 40: 228-240.

Timperley, M. H., R. R. Brooks \& P. J. Peterson, 1970. The significance of essential and non-essential trace elements in plants in relation to biogeochemical prospecting. Journal of Applied Ecology 7: 429-439.

Topcuoglu, S., 2001. Bioaccumulation of cesium-137 by biota in different aquatic environments. Chemosphere 44: 691-695.

Tuovinen, T. S., P. Roivainen, S. Makkonen, M. Kolehmainen, T. Holopainen \& J. Juutilainen, 2011. Soil-to-plant transfer is not linear: results for five elements and five boreal forest species. Science of the Total Environment 410: 191-197.

Ugedal, O., B. Jonsson, O. Njåstad \& R. Næumann, 1992. Effects of temperature and body size on radiocaesium retention in brown trout, Salmo trutta. Freshwater Biology 28: $165-171$.

Volesky, B. \& S. Schiever, 1999. Biosorption of Metals. In Flickinger, M. C. \& S. W. Drew (eds), Encyclopedia of Bioprocess Technology: Fermentation, Biocatalysis, and Bioseparation. Wiley, New York: 433-453.

Yoshutome, R., T. Kunito, S. Ikemoto, S. Tanabe, H. Zenke, M. Yamauchi \& N. Miyazaki, 2003. Global distribution of radionuclides $\left({ }^{137} \mathrm{Cs}\right.$ and $\left.{ }^{40} \mathrm{~K}\right)$ in marine mammals. Environmental Science and Technology 37: 4597-4602. 